\title{
Striving for Economic and Political Sustainability
}

\section{Andy Rothman}

\section{(2) OpenEdition}

Journals

Édition électronique

URL : http://journals.openedition.org/chinaperspectives/2053

DOI : 10.4000/chinaperspectives.2053

ISSN : 1996-4617

\section{Éditeur}

Centre d'étude français sur la Chine contemporaine

\section{Édition imprimée}

Date de publication : 15 septembre 2007

ISSN : 2070-3449

\section{Référence électronique}

Andy Rothman, "Striving for Economic and Political Sustainability », China Perspectives [En ligne], 2007/3 | 2007, mis en ligne le 01 septembre 2010, consulté le 28 octobre 2019. URL : http:// journals.openedition.org/chinaperspectives/2053; DOI : 10.4000/chinaperspectives.2053

(C) All rights reserved 


\title{
Striving for Economic and
} Political Sustainability

\author{
ANDY ROTHMAN
}

Hu Jintao, China's president and Communist Party chief, is asking his government to abandon its 25-year-old policy of striving for the fastest possible economic growth, regardless of the costs to society and the environment. Instead, he wants China to balance sustainable growth with a programme to redress the many negative consequences of two decades of 9\%-plus GDP growth. Although we do not expect Hu to fix China's health care system or to deliver a clean and green environment in just five years, we do anticipate enough progress to be achieved so that when the inevitable economic downturn arrives in five to ten years, the country will avoid political and social chaos. And while Hu is willing to accept slightly slower economic growth to manage the problems that threaten social stability, he continues to understand that a strong economy is the foundation for a harmonious society.

$\mathrm{T}$ he Seventeenth Party Congress provides $\mathrm{Hu}$ Jintao, China's president and Communist Party chief, with an opportunity to set the policy agenda for his second five-year term, as well as line up his successor. All of Hu's key decisions will be focused on promoting policies designed to achieve a "harmonious society" in China. His task will not be easy, as his plans create many apparent contradictions and are at odds with the approach taken by Party leaders over past decades.

$\mathrm{Hu}$ is asking his government to abandon its 25-year-old policy of striving for the fastest possible economic growth, regardless of the costs to society and the environment. Instead, he wants China to balance sustainable growth with a programme to redress the many negative consequences of two decades of 9\%-plus GDP growth. It will not be easy for $\mathrm{Hu}$ to convince the millions of officials who serve him across the country to change the way they behave and spend their budgets. These are, after all, bureaucrats who have always worked under the policy that faster is better. Faster growth in GDP, tax revenue and job creation meant faster promotions. "Soft" criteria such as pollution and school drop-out rates rarely entered into the personnel calculus.
Before $\mathrm{Hu}$ can even begin to tackle the many tough problems standing in the way of creating a harmonious society, he must first convince sceptical local governments and Communist Party organisations that his new, less growth-centric approach makes sense. This will be as big a challenge as cleaning up China's filthy rivers and reducing rampant corruption.

As the leadership prepares for the Party Congress, we imagine that $\mathrm{Hu}$ has asked the policy research office of the State Council (his cabinet) to prepare a report explaining the "harmonious society" concept. This will be Hu's primary opportunity to convince senior Party officials to put all of their political weight behind implementation of the programme.

What follows is our interpretation of what this State Council report to Party Congress delegates might look like. It is presented in the belief that Hu's "harmonious society" campaign will have a profound impact on government spending and regulatory policy-and thus the Chinese economy and investment environment-over the coming five years. The success of Hu's campaign will also be critical to the ability of the Chinese government to manage the social and political consequences of the economic downturn which will inevitably come to the mainland during the next five to ten years. 


\section{"Dear Party Congress delegates,}

We have been very lucky. Over the last 15 years, China's GDP growth has ranged between $7 \%$ and $14 \%$ and we have not experienced a single economic or financial crisis.

We have also avoided any serious social crises.

But we would be foolish to expect this long streak of good luck to continue indefinitely. As our economy becomes more market-oriented, an economic downturn, accompanied by high unemployment, is inevitable.

And history tells us that a sustained period of economic growth does not guarantee social and political stability. Europe's Industrial Revolution was, for example, followed in fairly short order by the social revolutions of 1848. It is instructive to briefly review that experience.

\section{The Industrial Revolution and China}

In the 1780s, at the start of the Industrial Revolution, Europe had much in common with present-day China. Europe was overwhelmingly rural then, and today $60 \%$ of Chinese live in the countryside. Agriculture was largely inefficient in Europe then, as it is in China now. And most people were poor: the average annual per-capita consumption of tea in England was barely two ounces.

But the Industrial Revolution-what some who do not know Chinese history call the most important event in world history-changed everything. With government policy supporting the private sector and profits, the modern factory was invented and trade took off. The export of British cotton increased more than ten times and unprecedented wealth was created.

That rapid growth and astounding wealth did not come without negative consequences. "The Industrial Revolution created the ugliest world in which man has ever lived, as the grim and stinking, fog-bound back streets of Manchester already testified." According to eminent scholar Eric Hobsbawm:

"Towns and industrial areas grew rapidly, without plan or supervision, and the most elementary services of city life utterly failed to keep pace with it: streetcleaning, water-supply, sanitation, not to mention working-class housing.

The transition to the new economy created misery and discontent, the materials of social revolution. And
Graph 1. China's GDP growth

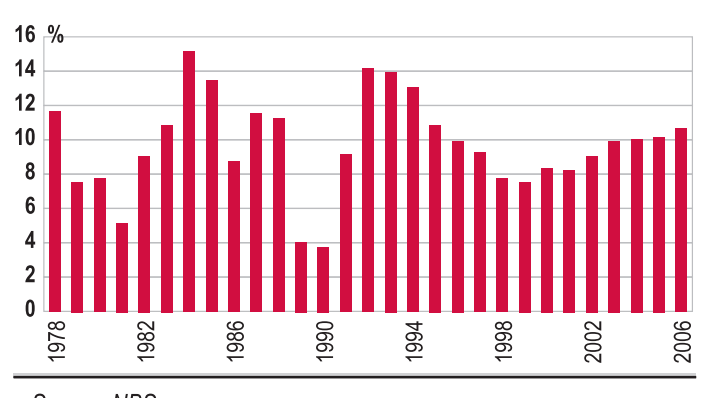

Source: NBS

indeed, social revolution in the form of spontaneous risings of the urban and industrial poor did break out, and made the revolutions of 1848 on the continent, the vast Chartist movement in Britain. Nor was the discontent confined to the labouring poor. Small and inadaptable businessmen, petty bourgeoisie, special sections of the economy, were also victims of the Industrial Revolution and of its ramifications. Simpleminded labourers reacted to the new system by smashing the machines which they thought responsible for their troubles; but a surprisingly large body of local businessmen and farmers sympathised profoundly with these Luddite activities of their labourers, because they too saw themselves as victims of a diabolical minority of selfish innovators.

Such was the situation of the labouring poor, and especially the industrial proletariat which became their nucleus, that rebellion was not merely possible, but virtually compulsory. The revolution of 1848 was its direct consequence."

Many of you will recognise some of the precursors to the 1848 revolution from our current situation in China. And it is worth recalling what happened when an economic crisis due to failed harvests and industrial recession ignited the unstable social climate: revolutions across the European continent that led to the fall of many leaders, the break-up of an empire, and the spread of parliamentary governments.

There are many differences between Europe of the early 1800s and modern China, but there are enough similarities to remind us that we cannot rest on our achievements of the past two decades. As in Britain, our successes have left many 
behind, and those citizens will eventually make their voices heard-unless we proactively address their concerns.

\section{We are not immune to recessions}

We must also acknowledge that our long, uninterrupted streak of economic growth does not mean we are immune to recessions and financial crises. All market economies are subject to recessions, and now that $70 \%$ of our GDP comes from the private sector, we should assume that a recession lies somewhere over the horizon. All emerging markets, no matter how successful, have experienced financial crises. The US, as an emerging market, was a good example: there were financial crises in 1819 , $1837,1857,1873,1884,1890$ and 1893. Several of those crises were connected with or followed by protracted depressions.

Economists are not very good at predicting exactly when such a crisis may come, or the specific problem that may trigger it, but statisticians can tell us with confidence that the odds are that we will experience an economic or financial crisis during the coming ten years. The current economic environment is certainly strong, so we can be optimistic and believe we have about five years to prepare, but we must not deny that the medium-term risks are significant.

Party Congress delegates, we face many huge challenges-from a broken health care system to environmental disaster, as well as rural poverty, corruption and the absence of the rule of law-but we should read this list as a call to action, not as a sign of impending catastrophe. China has overcome equally daunting challenges in the recent past.

\section{We have an appetite for risk}

During the past two decades, our predecessors in the Party leadership have shown foresight-and an appetite for risk. We have taken radical steps to ensure continued economic growth and social stability, which has meant continued leadership of the Party.

Some of those steps may not seem quite so radical with the passage of time, so it is worth reviewing them here:

Recognising that the command economy was unsustainable, between 1995 and 2001 we laid off 46 million state-sector workers-equal to sacking the combined workforce of France and Italy in six years.

We privatised the housing market, moving quickly from $15 \%$ to $70 \%$ urban homeownership. Some have called this transfer of previously state-owned housing to the workforce the largest one-time transfer of wealth in the history of the world We relaxed controls over entrepreneurs, which allowed the private-sector contribution to GDP to rise from only $17 \%$ in 1990 to $70 \%$ today.

We withdrew government control over prices of almost all goods and services, allowing them to be set by the market. We built a very impressive economic infrastructure in our cities, and since 2000 have added electric power generating capacity equal to the combined installed capacity of the following countries: Thailand, Poland, Ukraine, Spain, Italy, South Korea and the UK.

We opened our markets to the outside world and joined the WTO. As a measure of openness, imports make up 30\% of our GDP, about double the ratio in Japan and the US.

We significantly reduced Party intervention in the daily life of our people, providing them with much greater personal freedom, including access to information and the right to criticise their government.

So while earlier we said we have been lucky to avoid crises in the past fifteen years, actually, we have taken many proactive steps to create our own luck. Our predecessors in the Party leadership learned from their mistakes, and from the history of other nations. We must continue to learn from our mistakes and take similarly radical steps to deal with the problems China now faces.

\section{Dealing with negative consequences}

The most fundamental problem is dealing with the negative consequences of twenty-five years of unrestrained economic growth. Poverty persists in the countryside and income inequality has been rising. Our education and health care systems fail to serve hundreds of millions of poor Chinese. Our environment is heavily polluted and many of our local officials are corrupt. Few of our citizens are protected by health insurance or pensions. The absence of the rule of law makes it more difficult to resolve all of these problems and deprives our people of a sense of justice, equality and opportunity.

All of these problems have led to tension where there should be harmony. And this social tension will be exacerbated significantly when the inevitable economic downturn arrives. When the downturn hits, it will be the first one we have experienced since establishment of the market economy. This means it will be the first 
downturn in an economic structure where most of the growth and most of the employment comes from private companies. In past downturns, the Party could instruct state-owned firms, which dominated the economy, to continue producing, even if they could not sell their products. In the next downturn, this will be impossible. Private firms will shut their doors. Workers will lose their jobs. This will be a new experience for modern China.

In past downturns, those workers lived in housing provided by their state firm. Now, if they lose their jobs, how will they pay their mortgages?

In past downturns, education was provided by state firms. Now, how will the unemployed afford to pay the fees necessary to keep their children in school?

In past downturns, healthcare was also provided by state firms. Now, how will unemployed private-sector workers pay for their children or their parents to see a doctor?

This is why Party General Secretary Hu has directed us to begin taking concrete steps towards building a harmonious societybefore an economic crisis develops. If we do not act now, we run the risk of that economic crisis cascading into social chaos and political instability.

\section{Our task is easier}

Our task sounds daunting, but is actually easier than that of our predecessors. They had to initiate fundamental changes to the structure of China's economy and society, changes which raised deep and often divisive ideological questions. We, however, are faced in many cases with simply effectively implementing and enforcing programmes and rules that are already in place. We have, for example, a programme for compulsory education-we must now enforce and fund it. We have rules to protect the environment, which we must now enforce. We have laws to combat corruption, and we must now enforce them in a fair and transparent manner. None of our challenges raise ideological problems.

We are also fortunate that our government is in good fiscal health, so we have the money necessary to accomplish our task. In recent years, tax revenue has been growing at $20 \%$ annually, and the fiscal deficit is only $1.3 \%$ of GDP. Total central government debt is only $18 \%$ of GDP, and we have more than US $\$ 1$ trillion in foreign exchange reserves to serve as a buffer during a financial crisis.

In other words, we have no excuses not to act boldly."

\section{What "Harmony" Means for China's Economy and for Investors}

The previous section of this article is our interpretation of the internal discussion we believe is taking place within the Communist Party as $\mathrm{Hu}$ Jintao attempts to win support for his "harmonious society" campaign. Now we will look at the impact of the campaign on government spending and regulatory policy-and thus the Chinese economy and investment environment-over the coming five years. The success of Hu's campaign will also be critical to Beijing's ability to manage the social and political consequences of the economic downturn which will inevitably come to the mainland during the next five to ten years.

\section{Macroeconomic policy}

At first glance, "harmonious society" may sound like an anti-growth policy, with a focus on the environment, income inequality and providing better social services. Take a second look.

China's Communist Party is still a pro-growth government, but the objective is now balanced, higher-quality growth. $\mathrm{Hu}$ and Premier Wen Jiabao are willing to sacrifice a bit of speed to manage the problems that threaten social stability, but it would be a mistake to read a desire for 8\%-9\% GDP growth versus 11\%-12\% as antigrowth. $\mathrm{Hu}$ and Wen understand that strong economic growth is the foundation for a harmonious society.

Strong growth generates the fiscal revenue to pay for better health care and education. Strong growth translates into income growth, reducing rural poverty and delaying the day when widening income inequality becomes a serious social problem.

Strong growth is key to job creation, the leadership's top short-term worry. Real urban unemployment is likely in the 7\%-9\% range (as opposed to the official 4\% rate), and higher levels would strain urban social services and cut into the important flow of funds from migrant workers back to poor rural counties. The government hopes the economy will create nine million jobs this year, to accommodate some of the five million college graduates and seven million others who will enter the workforce. There are very few reasons for the government to take steps to cool off an economy which is not overheated. Since the fourth quarter of last year the Chinese econo- 
my has reaccelerated, as indicated by the first increases in three years of growth rates of electric power generation and industrial profits and margins. But you can ignore the official GDP growth number for the first half of 2007-11.5\%-as Beijing is stuck with working from the political fiction (too high) it has been issuing for the past few years. The economy is picking up, but after three years of slowing from a peak of 11\%-12\% in 2003. By our calculations, growth is accelerating a bit from a rate of $8 \%-9 \%$ last year, rather than double-digit figures. The first half numbers do not signal overheating, or the coming of serious government tightening measures.

We will see more of the quality-control measures (or token tightening) that were implemented over the last year: additional small interest-rate hikes and more increases in bankreserve ratios. But these are designed to raise the cost of capital to a more rational level, to restrain bankers from lending like drunken sailors who have just hit the shore and met cute $\mathrm{CFO}$ s showing off their voluptuous profits. The macroeconomic impact of these measures will be similar to what we have seen in the recent past: not much.

Yes, consumer price inflation is rising-5.6\% in July, up from $2.2 \%$ in January-but almost all of the increase has come from food. The government will not panic, understanding that this is a largely temporary, supply-driven problem, and that higher interest rates in China would have little impact on low domestic pork supplies or on high global corn and soybean prices. For the first seven months of the year, food accounted for $80 \%$ of the $3.5 \%$ increase in CPI.

\section{Investment}

From 2003 through 2006, fixed asset investment (FAI) increased by $24-27 \%$ annually, and we expect the growth rate to remain close to this range through the end of the decade. This means China will continue to drive global growth in demand for a broad range of commodities, from oil to copper and nickel.

Several factors will combine to keep FAI expanding at this rapid rate.

First, strong corporate profitability. Companies account for three-quarters of gross capital formation, most of which is financed by retained earnings, and profit growth is strong. Even though the growth rate of industrial firm profits fell sharply between 2003 and 2005, profit growth was still $27 \%$ in 2005 . Profitability improved in the fourth quarter of last year; pushing up profit growth to $31 \%$ for 2006. In the first five months of this year, lower prices for industrial
Graph 2. Growth of house prices and urban per-capita disposable income

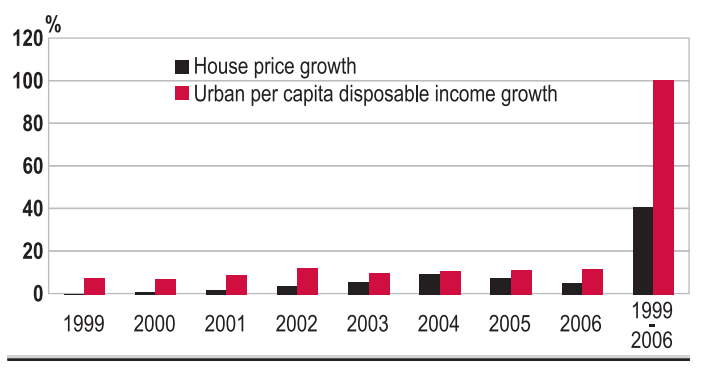

Source: CLSAAsia-Pacific Markets

\section{Graph 3. Mortgage growth}

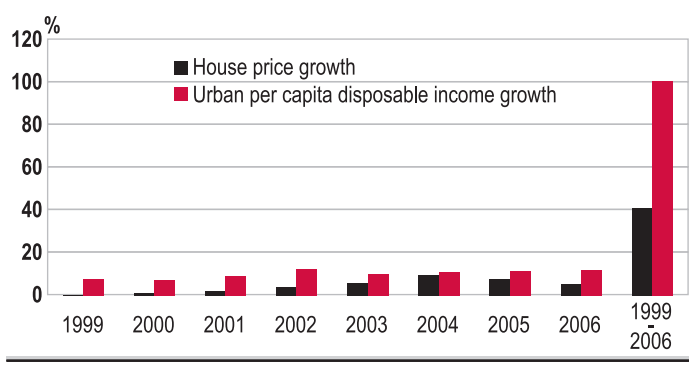

Source: CLSAAsia-Pacific Markets

inputs boosted profit growth even further, to $42 \%$ year on year. Firms will respond by raising capex spending; pressed by the government, some of this capex will be dedicated to pollution-control devices and equipment to replace outdated technology that wastes power, water and other scarce resources.

Second, the housing market will remain healthy. Households account for another 15\% of total investment, mostly for housing. House prices have risen significantly in recent years, but so has urban income. Nationally, house prices rose $41 \%$ from 1999-2006, but income jumped $101 \%$. As in all countries, there are geographical differences, and in Shanghai house prices outpaced income, by $127 \%$ versus $89 \%$. But, for most urban Chinese, housing has become more affordable over the last six years, helped by the recent availability of mortgages. (Nationally, in the first half of this year, real urban disposable income rose by $14.2 \%$, while house prices rose by $6 \%$.) We expect the government to continue to promote home ownership, especially by low- and middleincome families.

Third, government infrastructure spending will increase. The government accounts for about $10 \%$ of investment, 
Table 4. Growth of house prices and urban per-capita disposable income

\begin{tabular}{|c|c|c|c|c|c|c|c|}
\hline & $\begin{array}{l}\text { Planned } \\
\text { lines }\end{array}$ & $\begin{array}{l}\text { Finished } \\
\text { lines }\end{array}$ & $\begin{array}{c}\text { Total } \\
\text { length } \\
(\mathbf{k m})\end{array}$ & $\begin{array}{l}\text { Completed } \\
\text { length }(\mathrm{km})\end{array}$ & $\begin{array}{c}\text { Planned } \\
\text { investment } \\
\text { (Rmb bn) }\end{array}$ & $\begin{array}{c}\text { Current } \\
\text { investment } \\
\text { (Rmb bn) }\end{array}$ & $\begin{array}{l}\text { Planned } \\
\text { Finish }\end{array}$ \\
\hline Beijing & 19 & 5 & 561.5 & 114 & 100 & 12 & 2020 \\
\hline Shanghai & 13 & 5 & 510 & 123 & 140 & 49.2 & 2012 \\
\hline Guangzhou & 9 & 2 & 200 & 39.8 & 100 & 35 & 2010 \\
\hline Shenzhen & 5 & 2 & 124 & 23 & 37 & 12 & 2010 \\
\hline Tianjin & 9 & 2 & 234.7 & 41.1 & 84.01 & 11.04 & 2016 \\
\hline Hangzhou & 8 & 0 & 278 & 0 & 100 & 45 & 2050 \\
\hline Nanjing & 14 & 1 & 433 & 22 & 173 & 8.8 & 2009 \\
\hline Harbin & 3 & 0 & 46 & 0 & 16.3 & 4.52 & 2013 \\
\hline Shenyang & 5 & 0 & 46 & 0 & 82 & 9.5 & 2012 \\
\hline Qingdao & 5 & 0 & 128 & 0 & 56 & 0 & 2050 \\
\hline Zhengzhou & 1 & 0 & 34.16 & 0 & 10.7 & 0 & 2014 \\
\hline Xi'an & 6 & 0 & 50.3 & 0 & 17.9 & 0 & 2050 \\
\hline Chengdu & 7 & 0 & 54 & 0 & 19.7 & 0 & 2050 \\
\hline Chongqing & 10 & 1 & 522 & 14.35 & 100 & 4.3 & 2050 \\
\hline Changchun & 2 & 0 & 42 & 0 & 39.6 & 0 & 2050 \\
\hline
\end{tabular}

Source: CLSA Asia-Pacific Markets

China handles one-quarter of the world's rail traffic on just $6 \%$ of the world's total track length, and the system turns away about as much cargo as it carries, so we expect significant investment in the network.

From 2005 to 2010 the number of deepwater berths at China's ports will increase from 393 to 1,183, and the expected investment on container ports alone will reach 185 billion yuan [US $\$ 24$ billion].

Beijing has reportedly budgeted 52 billion yuan [US $\$ 6.7$ billion] for the construction of 37 new airports and expansion of 31 others, including Shanghai's two airports. Hongqiao will more than double its current 15 million passenger capacity, and Pudong's second phase will open in 2008, tripling its capacity to 60 million passenger throughput.

This continued high level of investment is obviously very bullish for global commodity demand. Over the last decade, China accounted for $61 \%$ of the increase in world consumption of steel, including $41 \%$ of the global increase in 2006. China also generated more than half of the increase in global consumption of copper and aluminium during the last ten years, including one-third of last year's increase in copper consumption.

And China is increasingly dependent upon imports to feed this voracious appetite for commodities. Ten years ago, imports accounted for only $12 \%$ of China's oil consumption, but that share is now close to $50 \%$. The share of imported iron ore, copper and nickel have all risen significantly as well.

\section{Heavy industry consolidation}

The harmonious society effort to reduce pollution and raise energy and resource-use efficiency will, over the coming years, result in consolidation of many of China's dirtiest heavy industries. In sectors such as steel, chemicals, paper and metals processing, enforcement of environmental protection laws will result in the closure of large numbers of smaller firms that cannot afford to install the required equipment. Local officials will also be under pressure from Beijing to use environmental grounds to shut firms that are inefficient users of energy but cannot afford to install more advanced technology.

Dozens of small steel mills, for example, are surviving by exporting low-grade construction steel that is priced significantly higher abroad than it is on the mainland, but that leaves China exporting resources which are in short supply: 
Graph 5. China drives global growth (1995-2006)

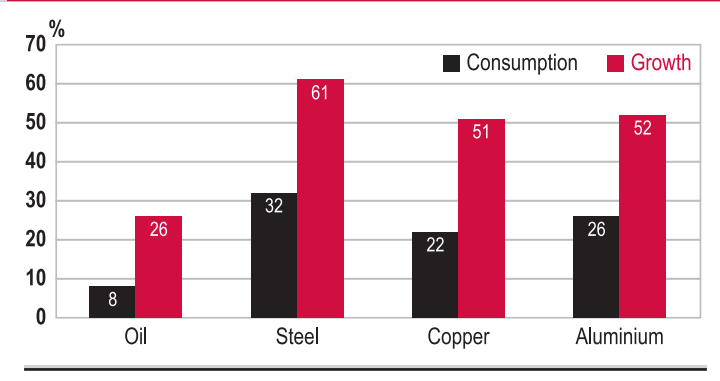

Source: CLSAAsia-Pacific Markets

\section{Graph 6. China's rising import dependency}

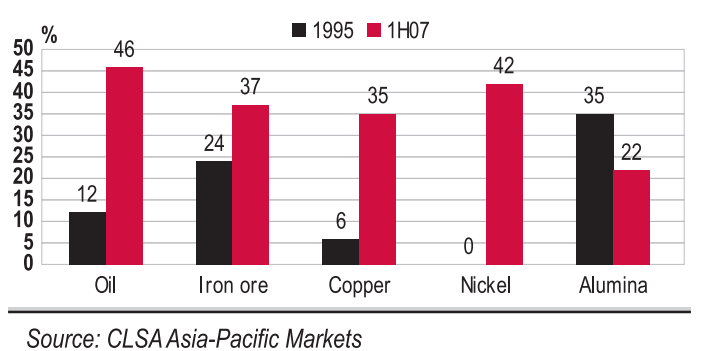

Source: CLSA Asia-Pacific Markets

energy, iron ore and water. There is plenty of room for consolidation, as 74 of the country's 200 mills account for $65 \%$ of total steel production.

The government would also like to raise the efficiency of resource recovery in the coal industry, by shutting about half of the 22,000 small mines, operations which usually do not meet pollution (or worker safety) requirements.

Larger companies-in general, the listed firms in these sectors-will have to spend quite a bit to become compliant with pollution and energy efficiency regulations, but this cost will be outweighed by the impact of consolidation. Most sectors are plagued by overcapacity, which is the primary reason margins have been squeezed in recent years. The closure of a significant number of smaller producers should allow the larger, listed firms to regain some pricing power, more than making up for the added expense of cleaning up their emissions.

\section{Regulatory policy}

The harmonious society campaign will have a large impact on government regulatory policy, as the Party seeks to reduce corruption opportunities and boost the private sector. It is clear that over-regulation provides many channels for corruption, as companies must seek a wide range of approvals from local officials just to engage in routine business. As the Party works to reduce the level of rent-seeking opportunities for officials, we expect Beijing to relax controls over mergers and acquisitions by domestic firms, particularly privately owned companies. There will also be increased merger and acquisition opportunities for foreign firms, but the government will continue to limit foreign access to sectors considered strategic, including financial services.

We also expect the Party to build on the steps taken at this year's National People's Congress towards creating a stronger foundation for an entrepreneur-driven, market-based economy. Premier Wen, the number two man in the world's number one Communist Party said his government will "actively support the efforts of individuals to start their own businesses." And his finance minister added that "We will continue supporting the policy-mandated closing and bankruptcy of state-owned enterprises ... [and] we will support the development of small and medium-sized enterprises."

Party support for entrepreneurs was signalled most clearly when it was announced that the new corporate income tax law passed by the NPC includes a tax break for small firms-probably the first time the Party has given entrepreneurs a direct advantage over larger state-owned companies. Of course, the private sector already accounts for $70 \%$ of GDP and almost all new job creation, but an extra endorsement from the Party leadership will help clear away some of the political obstacles entrepreneurs often face from bankers and local officials.

The NPC also passed a property law which sends a clear message to judges and local officials: "No matter if it is state, collective or private property, it should be protected equally. Otherwise people's enthusiasm to create and accumulate wealth in legal ways will be impaired, and the country's prosperity and social stability will also be harmed," according to the NPC's spokesman.

We also expect regulatory progress on financial services, granting domestic firms the flexibility to offer a wider range of products, while raising the level of oversight to reduce corruption and raise investor confidence. With $86 \%$ of China's financial wealth held in cash (versus 19\% in the US), this will open a goldmine of opportunity. We have already seen examples of the possibilities, with assets under management by the funds industry climbing by $50 \%$ last year, and we expect life-insurance premium revenue to rise $15 \%$ this year.

\section{Consumption}

Finally, if the harmonious society campaign is successful, 
Graph 7. Distribution of financial assets

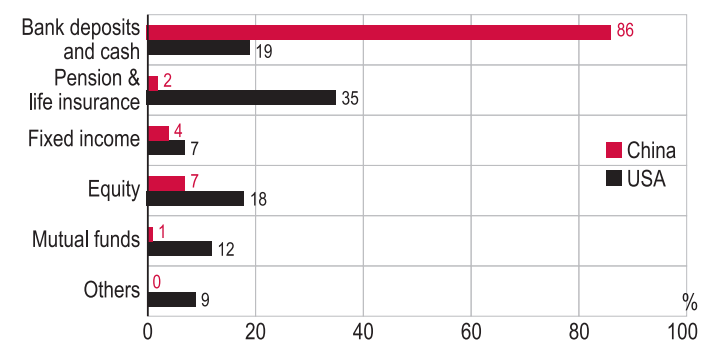

Source: CLSA Asia-Pacific Markets

and people believe that significant progress is being made towards creating a viable social safety net and relieving their burden for health care and education costs, household savings rates will slowly start to come down from the current high levels (equal to $30 \%$ of GDP and 16\% of household disposable income), boosting the private consumption share of GDP. Retail sales have grown by more than $10 \%$ annually for the past several years, and by $16.4 \%$ in the first seven months of this year, so there is no doubt that a consuming culture is firmly entrenched in China. Consumer finance will continue to expand-the number of credit cards rose to 20 million last year from 0.5 million in 1999-facilitating the sale of consumer durables.

\section{Concluding Remarks}

With $\mathrm{Hu}$ Jintao clearly determined to make progress towards a "harmonious society" the focus of his second and final term as Party Chief, we expect to see substantial progress on the social, environmental and political problems that he has targeted. Although we do not expect $\mathrm{Hu}$ to fix China's health care system or to deliver a clean and green environment in just five years, we do anticipate enough progress to be achieved so that when the inevitable economic downturn arrives in five to ten years, the country will avoid political and social chaos. And while $\mathrm{Hu}$ is willing to accept slightly slower economic growth to manage the problems that threaten social stability, he continues to understand that a strong economy is the foundation for a harmonious society. 